\title{
MANAGING OF RECEIVABLES IN THE CASE OF RESERVES IN MINE WINDING CAPACITY
}

\section{Introduction}

The activity of every enterprise in a market economy, including mines, is related to the necessity of accepting the existence of receivables, besides many other conditions. These receivables are not in their nature economically disadvantageous, nonetheless, in many cases, they may lead to a loss of financial liquidity or even bankruptcy. Receivables are a type of credit for recipients and are usually referred to as trade credit. Trade credit, in this case, is the applied method of management of dues, and although it has many advantages, it also has significant flaws. Among the most important advantages of trade credit is the possibility of increasing sales, which leads to improved financial liquidity. The main disadvantages of trade credit are often the tightening of cash flows, the risk of excessive prolonging of deadlines for payment of dues, or even loss of these dues. In [1], receivables for deliveries and services were, for the sake of an example, divided into three groups:

- certain dues,

- uncertain dues,

— lost dues, including amortized dues, uncollectable dues, and expired dues.

There is, in practice, no one model for managing receivables relative to clients. Subject literature, e.g. [1-5], proposes to apply receivables management by means of the following activities:

- monitoring of receivables,

- securing of receivables,

- vindication of receivables,

- turnover of receivables,

— utilization of trade credit and discount options.

In this case, within the limits of trade credit and rebate options, an appropriate solution would need to be implemented by the seller, who should use the above means. Clients

* AGH University of Science and Technology, Krakow; t-zak@agh.edu.pl 
should be assessed in particular, for example, according to their turnover value, punctuality of dues payment, or on the basis of their economic and financial indexes.

As discussed above, there is no single model for managing receivables, and in each case, the solution will depend not only on measurable factors but also on the seller's attitude towards taking risks. It can therefore be stated that receivables management, including credit policy, is realized in three ways [2-5]:

- conservatively, when the seller, as a rule, establishes conditions for delivery of goods or rendering of services with prior payment of dues, trade credit is granted to steady clients of many years or after implementing the appropriate securities,

- moderately, without solutions that are as resolute as those mentioned above, but with the implementation of the systematic monitoring of recipients, whereby the next delivery can be realized only after the regulation of current receivables by the recipient, - aggressively, permitting granting of trade credit to practically all recipients without regard to the risk, nonetheless, this is a naturally risky method, used in the case where the seller wants to broaden his list of recipients or increase sales.

The term trade credit is understood as a situation where the seller accepts payment of receivables by the recipient within a deadline which is significantly longer than the deadline of goods delivery or rendering of a service. The length of the period prior to the deadline for the payment of the trade credit is dependent on the method of receivables management accepted by the seller.

In receivables management or the application of trade credit, rebates are generally used and commonly understood as a decrease of the established price of goods or services. Despite the universality of the application of rebates in economic turnover, the literature, e.g. [3-5], as well as tax [6] or balance sheet [7] law use many different terms as synonyms of rebate.

For precise statement of this term, art. 29 par. 1 and 4 of the law on goods and services tax [8] was applied, which states: "The basis for taxation is turnover. Turnover is the amount due for sale, decreased by the amount of tax due. Turnover is decreased by amounts of documented, legally acceptable, and obligatory rebates (allowances, discounts, recognized claims, and prompt payment discounts)".

Therefore, the act lists a closed list of terms as variations of a rebates and short interpretations of these terms are presented as follows [9]:

- an allowance is mainly a decrease in the established price of goods or services, especially as a form for possible loss,

- a discount signifies a price deduction on goods or services, most often in regard to wholesale purchases,

- a recognized claim is the right of a buyer of goods or services to decrease the price in the case of a justified claim,

- a prompt payment discount is a decrease in the price of goods or services granted to the buyer if he pays in cash or before the payment deadline specified in the contract.

In the example below, one of many methods of using discounts to improve receivables collection has been presented, and specifically, the situation of a mine that is not utilizing its winding and processing capability and is therefore producing and selling its products in amounts that are less than the aforementioned winding and processing capacity. 


\section{Increasing utilization of winding and processing capacity in relation to discounts}

The amount of products produced and sold by a mine that is less than its winding and processing capability may result from several causes:

- uncoordinated capabilities of individual links of the entire winding and processing process,

- bad organization of the winding and processing process,

- limited sales of mine products on the market due to:

- bad product quality,

- a product sales price used by the mine that is too high.

Let it be accepted hereinafter, that the only factor limiting the capability of increasing production and sales to the value of winding and processing capability is the product price set by the mine.

To explain this problem, the following example of a mine will be used, which, during turnover year X, was characterized by the following data:

- the winding capacity of the mine is equal to: $Z_{w}=1.2 \mathrm{mln} \mathrm{Mg}$,

- production in this time was equal to: $x=1.0 \mathrm{mln} \mathrm{Mg}$,

- sales were equal to production; that is $x_{p}=1.0 \mathrm{mln} \mathrm{Mg}$,

- operating production costs were equal to; $K_{o}=K_{s}+k_{j z} \cdot x_{p}=45.0 \mathrm{mln}$ PLN, including:

- fixed costs; $K_{s}=30.0 \mathrm{mln}$ PLN,

- variable costs; $K_{z}=15.0 \mathrm{mln}$ PLN,

- unit variable cost; $k_{j z}=15.0 \mathrm{PLN} / \mathrm{Mg}$,

- unit sales price; $p=50.0 \mathrm{PLN} / \mathrm{Mg}$,

- sales income; $P_{o}=p \cdot x_{p}=50.0 \mathrm{mln}$ PLN,

- operating profit, $Z_{o}=\left(p \cdot x_{p}\right)-K_{o}=5.0 \mathrm{mln}$ PLN,

- break even point; $B E P=\frac{K_{S}}{c-k_{j z}}=0.857 \mathrm{mln} \mathrm{Mg}$.

Considering the results listed above, it could be stated that the mine should not be experiencing problems, that is has a satisfactory operating profit, and that production and sales are greater than break even. It turns out, however, that after broader analysis, with regard to the profit and loss account and of cash flow, the mine is experiencing losses on financial activity with even greater problems in maintaining financial liquidity. Problems with punctual collection of receivables are the main cause of this.

Detailed analysis of receivables management was conducted, and it was stated that, at the current product sales price and with the existing competition, recipients are not able to buy more than $1.0 \mathrm{mln} \mathrm{Mg}$, and what is more, the mine was forced to accept an average dues rotation cycle of 45 days. The decisive majority of the mines obligations however, must be realized within a shorter time, and thus, it was necessary to take credit, which caused the aforementioned problems with financial liquidity. After the monitoring of recipients, deadlines of payment of dues, and product prices, the mine established new conditions of cooperation that were accepted by the recipients. In light of the possibility for increasing production and sales to the value of the winding capacity, recipients were able to increase purchases to a total amount of $Z_{w}=1.2 \mathrm{mln} \mathrm{Mg}$, on condition that the current price was decreased. 
The mine accepted these terms under the condition that recipients would agree to a shortening of the deadline for collection of dues to 30 days. The final establishments were reflected in the discount proposed by the mine [6]; $p_{s} / o_{s}$, net ok, where:

$$
\begin{aligned}
p_{s} & - \text { percentage of the granted discount, } \\
o_{s} & - \text { period of the discount, } \\
n e t & - \text { a term preceding credit payment, } \\
o k & - \text { period for payment of dues. }
\end{aligned}
$$

The percentage of the proposed rebate $\mathrm{p}_{\mathrm{s}}$ must be determined. To achieve this, the scheme presented in Figure 1 was used $[1,10]$.

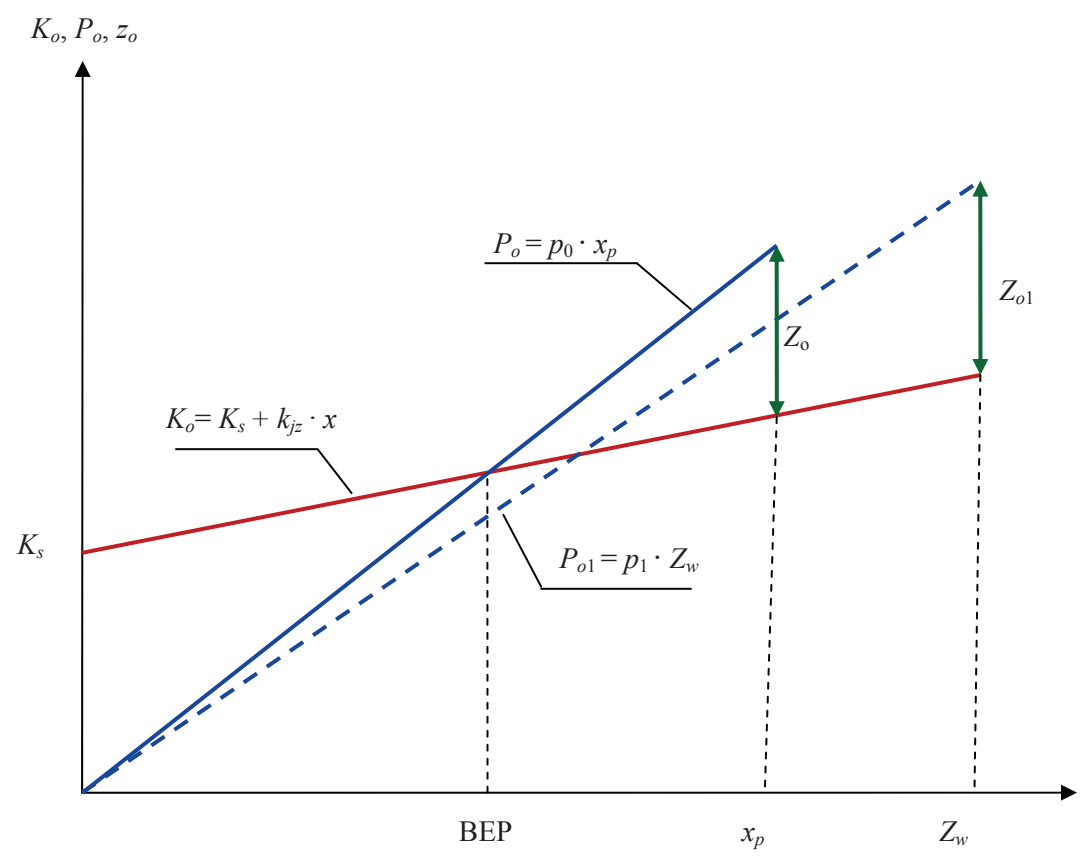

Fig. 1. Increase in sales with the application of a discount

The mine accepted the internal assumption that the decrease in price should not decrease the operating profit achieved up to the time of the discount. Therefore, at an increase in production and sales to the value of $x_{p}=Z_{w}=1.2 \mathrm{mln} \mathrm{Mg}$, for the operational profit to not be less than the value of $Z_{o}$ achieved up to this point, the sales price will be decreased to the value of $p_{1}$. Then, using Figure 1, it can be written that:

$$
Z_{o 1}=P_{o 1}-K_{o 1}
$$

where:

$P_{o 1}-$ value of sales revenue at an increase in sales and a decrease in price,

$K_{o 1}$ - operating costs at increased production (and sales). 
The above values are determined as follows:

$$
\begin{gathered}
P_{o 1}=p_{1} \cdot Z_{w} \\
K_{o 1}=K_{s}+k_{j z} \cdot Z_{w}
\end{gathered}
$$

Operational profit is determined from formula (1):

$$
Z_{o 1}=\left(p_{1} \cdot Z_{w}\right)-\left(K_{s}+k_{j z} \cdot Z_{w}\right)
$$

Using formula (4), the minimum value of the new price $p_{1}$ can be determined so that the operating profit was not less than its value from before the discount. Therefore, by converting formula (4), the following can be written:

$$
p_{1} \geq \frac{Z_{o}+\left(K_{s}+k_{j z} \cdot Z_{w}\right)}{Z_{w}}
$$

By substituting the above values to formula (5), the following is obtained:

$$
p_{1} \geq \frac{5,0 \mathrm{mln} \mathrm{PLN}+(30 \mathrm{mln} \mathrm{PLN}+15 \mathrm{PLN} / \mathrm{Mg} \cdot 1,2 \mathrm{mln} \mathrm{Mg})}{1,2 \mathrm{mln} \mathrm{Mg}} \geq 44,66 \mathrm{PLN} / \mathrm{Mg}
$$

The mine proposed a new price of $p_{1}=45.0 \mathrm{PLN} / \mathrm{Mg}$, and so, granted its clients a large rebate, decreasing the price by $10 \%$. The newly established conditions were written as follows: $10 / 30$, net 45 .

Signifying that a $10 \%$ rebate (decrease in price) will be respected by the mine under the condition that payment of receivables will take place by a deadline that is not longer than 30 days.

After these conditions were posed and the discount was applied, the mine achieved the following results:

- sales revenue; $P_{o 1}=45 \mathrm{PLN} / \mathrm{Mg} \cdot 1.2 \mathrm{mln} \mathrm{Mg}=54.0 \mathrm{mln}$ PLN,

- operating costs; $K_{o 1}=30.0 \mathrm{mln}$ PLN $+15.0 \mathrm{PLN} / \mathrm{Mg} \cdot 1.2 \mathrm{mln} \mathrm{Mg}=48 \mathrm{mln}$ PLN,

- operating profit; $Z_{o 1}=54.0 \mathrm{mln}$ PLN $-48 \mathrm{mln}$ PLN $=6.0 \mathrm{mln}$ PLN.

The rebate proposed by the mine, that is, a decrease in the product price to $45.0 \mathrm{PLN} / \mathrm{Mg}$, and shortening of the deadlines for the payment of dues by recipients to 30 days helped the operating profit for the next year to increase by $1.0 \mathrm{mln}$ PLN, that is, to $6 \mathrm{mln}$ PLN, and at the same time, the mine did not have to take credit to fulfill current obligations. At the same time, financial costs resulting from the need to pay interest on credit disappeared, and more importantly, the mine now maintains ongoing financial liquidity.

\section{Increase in utilization of production capability with an increase of the period for dues collection}

An enterprise's credit policy can be realized for the purpose of achieving specific goals and also using various methods. In the previous situation, the application of a discount for the purpose of utilizing free production capability was discussed. The following example presents a method for utilizing free production capability with the application of the so-called method of incremental analysis $[2,3,5]$, according to which, benefits resulting 
from increased sales are balanced with costs that must be sustained to provide more advantageous conditions for recipients under the condition of increased purchases by recipients.

To explain the proposed method in more detail, an example from the previous point was used. Thus, there is an enterprise with a winding capacity of $Z_{w}=1.2 \mathrm{mln} \mathrm{Mg}$, production and sales of $x=x_{p}=1.0 \mathrm{mln} \mathrm{Mg}$, and a sales revenues of $P_{o}=50.0 \mathrm{mln}$ PLN, at a unit price of $p=50.0 \mathrm{PLN} / \mathrm{Mg}$, and operating costs of $K_{o}=45 \mathrm{mln}$ PLN, of which fixed costs were equal to $K_{s}=30.0 \mathrm{mln}$ PLN and variable costs $K_{z}=15.0 \mathrm{mln}$ PLN, with an operating profit of $Z_{o}=5.0 \mathrm{mln}$ PLN.

The difference is such that in this case, the proposed cycle of dues conversion is shorter and equal to 30 days. Despite this fact, the enterprise has problems with the ongoing maintenance of financial liquidity and wishes to use its reserve production capability to increase sales by $0.2 \mathrm{mln} \mathrm{Mg}$ without changing the unit price used up to this point. However, it proposes to prolong the current dues conversion cycle to 45 days from 30 days, in exchange for increase purchases.

The method of incremental analysis is based on balancing increased profit with an increase in unavoidable operating costs and increased costs of financing greater dues. After the acceptance of the proposal by recipients, individual results are presented as follows. Of course, sales revenues will be increased:

$$
P_{o 1}=1.2 \mathrm{mln} \mathrm{Mg} \cdot 50.0 \mathrm{PLN} / \mathrm{Mg}=60.0 \mathrm{mln} \mathrm{PLN}
$$

so the profit increment will be equal to:

$$
\Delta P_{o}=P_{o 1}-P_{o}=10.0 \mathrm{mln} \text { PLN }
$$

and operating costs will also increase:

$$
K_{o 1}=K_{s}+k_{j z} \cdot x_{p}=30.0 \mathrm{mln} \mathrm{PLN}+15.0 \mathrm{PLN} / \mathrm{Mg} \cdot 1.2 \mathrm{mln} \mathrm{Mg}=48.0 \mathrm{mln} \text { PLN }
$$

so operating costs will rise by:

$$
\Delta K_{o}=K_{o 1}-K_{o}=3.0 \mathrm{mln} \text { PLN }
$$

therefore, the profit increment will be equal to:

$$
\Delta Z_{o 1}=\Delta P_{o}-\Delta K_{o}=10.0 \mathrm{mln} \mathrm{PLN}-3.0 \mathrm{mln} \mathrm{PLN}=7.0 \mathrm{mln} \text { PLN }
$$

The average state of dues will increase by a value of [2]:

where:

$$
\Delta N=\left[\left(d_{1}-d_{0}\right) \cdot \frac{P_{o}}{360}\right]+d_{1} \cdot \frac{\Delta P}{360}
$$

$\Delta P-$ is the increment in the value of dues [PLN],

$d_{0}$ - the dues conversion cycle up to this point [days],

$d_{1}-$ the forecasted dues conversion cycle [days].

Therefore, by substituting the data obtained earlier, it can be written:

$$
\Delta N=\left[(45-30) \cdot \frac{50000000}{360}\right]+45 \cdot \frac{10000000}{360}=3333333,0
$$


To finance the increased value of dues, the enterprise took bank credit, the average cost $k_{k}$ of which, according to current data, is $9.5 \%$, so the total cost of credit for the increment of dues $\Delta K_{N}$ will be equal to:

$$
\Delta K_{N}=\Delta N \cdot k_{k}=3333333.0 \mathrm{PLN} \cdot 0.095=316666 \mathrm{PLN}
$$

The final profit of the proposed solution will be equal to:

$$
\Delta Z=\Delta Z_{o 1}-\Delta K_{N}=6683334 \mathrm{PLN}
$$

In this case, the applied method would also be profitable.

\section{Summary and final conclusions}

Conducting economic activity in a market economy is fraught with many risks, among which one of the most important is considered to be loss of ongoing financial liquidity. That is why the main goal of ongoing activity is not profit but the aforementioned financial liquidity. Liquidity, in turn, is strictly dependent on the cooperation of the recipients of produced products and the unavoidable receivables. More detailed studies indicate that in many cases, an increase in sales is related to the necessity of accepting an increase in dues, but their collection can be more and more difficult. The numerous cases of Polish construction enterprises that have been forced to declare bankruptcy by uncollectable dues are an example of this.

The calculations given here show how improvements in financial liquidity through the appropriate management of receivables are an example of the fact that these methods are not only possible in practice, but necessary. This does not mean that the solutions given here are always accepted, however, the entire scope of necessary activities which a mine must undertake as a creditor to minimize the risk of the loss of financial liquidity have also been mentioned in this work.

\section{REFERENCES}

[1] Kłak B.: Skutki ekonomiczno-podatkowe wykorzystania rabatu w procedurach windykacji należności przez przedsiębiorstwa górnicze. Praca doktorska, Kraków, AGH, Wydział Górnictwa i Geoinżynierii 2006

[2] Czekaj J., Dresler Z.: Zarządzanie finansami przedsiębiorstw. Podstawy teorii. Warszawa, PWN 1998

[3] Panfil M.: Zarządzanie należnościami w małym i średnim przedsiębiorstwie. Warszawa, PARP 2004

[4] Sierpińska M.: Wynik finansowy jako miernik gospodarności przedsiębiorstwa. Wiadomości Górnicze, nr 12, 2005, pp. 625-679

[5] Sierpińska M., Wędzki D.: Zarządzanie płynnością finansową w przedsiębiorstwie. Warszawa, PWN 1998

[6] Ustawa z dnia 15 lutego 1992 r. o podatku dochodowym od osób prawnych, Dz. U. nr 21, poz. 86 z późn. zm.

[7] Ustawa z dnia 29 września 1994 r. o rachunkowości, Dz. U. nr 121, poz. 591, z późn. zm.

[8] Ustawa z dnia 11 marca 2004 r. o podatku od towarów i usług, Dz. U. nr 54, poz. 535, z późn. zm.

[9] Słownik języka polskiego. Warszawa, PWN 1992

[10] Czopek K.: Koszty stałe i zmienne. Cz. 1. Teoria i praktyka. Katowice, Wydawnictwo „Śląsk” 2003

\section{Acknowledgments}

This article was written in 2013 under the statutory research registered in the AGH University of Science and Technology in Krakow at no. 11.11.100.481. 